\title{
The Irish referendum on the Lisbon Treaty
}

by Alfred E Kellermann

Do governments of EU Member States have to comply with loyalty and solidarity obligations deriving from Article 10 EC and Article 11(2) of the EU Treaty?

\section{INTRODUCTION}

$\mathrm{T}$ The Treaty of Lisbon was signed by the EU Member States in December 2007, which by common accord agreed to amend the Treaty on European Union, the Treaties establishing the European Communities, and certain related Acts.

The Treaty of Lisbon concludes a long process which started after the process of EU enlargement with 10 new Member States. In fact the Lisbon Treaty is a follow-up to the Laeken Declaration of the European Council of December 2001, the text of the Constitutional Treaty and the process of Treaty revision that had been re-started, after a period of reflection in June 2007, after the negative referenda in France and the Netherlands. The Laeken Declaration proclaimed that there is a need for improvements in the areas of democratic legitimacy and transparency of the EU institutions, the role of the national Parliaments, the efficiency of decision-making and the coherence in European foreign policy.

According to Article 48 of the Treaty on European Union (TEU), the amendments of the EU and EC Treaties will enter into force after being ratified by all the Member States in accordance with their respective constitutional requirements. If the Treaty of Lisbon will be ratified in accordance with the constitutional requirements of each Member State, it will enter into force according to the original timeframe on January 1, 2009.

Only one EU country, Ireland, out of 27 Member States, has, according to its Constitution, to approve the Lisbon Treaty by referendum. Ireland accounts for less than 1 per cent of the bloc's population of almost 500 million citizens. The "no" vote of June 13 has blocked the improvement for the Treaty and might detonate a political crisis.

The result of the referendum not to ratify the Lisbon Treaty - "yes" 46.5 per cent, "no" 53.5 per cent - does raise several political and constitutional questions for legal solutions that would finally allow for the ratification of the treaty (The actual percentages of rejection were more or less identical with those of the rejection of the Nice Treaty - see hereafter). The Irish referendum on the Lisbon Treaty is a recent example of the importance of national constitutions and its impact on European integration. In my opinion, for the further development of European integration it is neither acceptable nor democratic that less than approximately 1 million Irish voters can prevent progress for approximately 500 million European citizens by blocking further European integration, which was the objective of the Lisbon Treaty.

\section{REFERENDA IN OTHER STATES}

It is however not the first time that a referendum has formed an obstacle for the ratification of an European Treaty. There was a near failure to have the Maastricht Treaty ratified in Denmark and in France. In Norway the Accession Treaty was rejected by a referendum, the first time in 1973 and the second time in 1994. The Agreement on the European Economic Area was rejected in a subsequent national referendum in Switzerland in 1992.

On June 7, 2001 a referendum also held in Ireland on the Nice Treaty was negative: "no" 53.87 per cent and "yes" 46.13 per cent. This was more or less identical to the outcome of the Lisbon referendum. The Constitutional Treaty was rejected in 2005 by France and the Netherlands. In the following text some suggestions are given as a contribution to an exchange of ideas on the finding of legal and political solutions for these constitutional problems, focusing on the recent Irish referendum.

The Irish complaints against the Lisbon Treaty were quite varied, reflecting everything from fears over loss of influence in an enlarged EU to concerns that the EU's military plans might threaten Ireland's traditional neutrality and loss of VAT taxation benefits. In fact they are not directly related to the text of the Treaty, but to a large extent reflected disenchantment with further integration, which has been foisted on an unwilling electorate by political elites. The referendum culture in Ireland is very strong and, due to a series of political funding scandals, 
there is a deep cynicism towards politicians. Moreover, the electorate was assured in 1972 that with each significant step towards integration there would be a referendum (see A E Kellermann, "The Irish referendum on the Treaty of Nice and Article 10 EC - A recent example of constitutional problems of enlargement", in $E U$ Enlargement, the Constitutional Impact at EU and National Level, pp 499 - 502, Edited by Alfred E Kellermann, Jaap W de Zwaan and Jeno Czuczai, TMC Asser Press, 2001).

The next move for Ireland is unclear. Its EU partners have already ruled out a complete renegotiation of the complex treaty. The alternative is a political declaration attached to the treaty which seeks to meet Irish concerns. The central question is:

Do governments of EU Member States have to comply with the loyalty and solidarity obligations from Article $10 \mathrm{EC}$ and Article 11(2) EU with reference to the ratification of reform treaties which have been agreed by common accord within the European Council?

One of the main questions to be answered from a European law perspective is whether national governments -like for example the Irish Government - complied with the duty of loyalty to the EU as mentioned in Article 10 EC Treaty and in Article 11(2) EU Treaty.

Article 10 EC reads as follows:

"Member States shall take all appropriate measures, whether general or particular, to ensure fulfillment of the obligations arising out of this Treaty or resulting from action taken by the institutions of the Community. They shall facilitate the achievement of the Community's tasks. They shall abstain from any measure which could jeopardize the attainment of the objectives of this Treaty."

Article 11(2) EU Treaty reads as follows:

“The Member States shall support the Union's external and security policy actively and unreservedly in a spirit of loyalty and mutual solidarity.

The Member States shall work together to enhance and develop their mutual political solidarity. They shall refrain from any action which is contrary to the interests of the Union or likely to impair its effectiveness as a cohesive force in international relations.

The Council shall ensure that these principles are complied with."

The principal and essentially legal question which arises is whether Article 10 EC and Article 11(2) EU apply in this context at all for national constitutional ratification provisions. The first point concerns the implementation of the procedure and Article 10 EC cq Article 11(2) EU. The second point concerns the adaptation of the national constitutional provisions.

(1) Ratification according to article $10 \mathrm{EC}$ cq Article 11(2) EU obligation. Can the ratification provisions of
Article 48 TEU jo Article 313 (EC Treaty) be considered as obligations arising out of the EU and EC Treaty as required in the wording of Article 10 EC Treaty, or can these obligations only be considered as obligations arising out of international law after signing a treaty according to the 1969 Vienna Convention on the Law of the Treaties?

(2) Adaptation of national constitution according to Article 10 EC cq Article 11(2) EU obligation.

Do the implementation of the national constitutional ratification provisions of Article 48 TEU jo Article 313 (EC Treaty) also have to comply with the criteria of Article 10 EC cq Article 11(2) EU?

In other words: if the national constitutional provisions would be a serious obstacle for the ratification of an EU Treaty amendment, which had been agreed by common accord within the European Council between all the Member States, would the Member States in such a case be obliged to replace the respective national constitutional provisions, which require a referendum by another procedure? National constitutional lawyers argue that Article 10 EC will only apply to existing Treaty obligations which will enter into force only after ratification.

Would it not be possible, as the European Court of Justice has done in some earlier cases, to give a teleological interpretation also to the provisions of Article 313 EC Treaty ("This Treaty shall be ratified by the High Contracting Parties.....") so that these provisions can be considered as a community obligation of loyalty or solidarity in the meaning of Article 10 EC and 11(2) EU?

Perhaps a teleological interpretation of these articles may enlarge the applicability of Article 10 EC to agreements concluded in unanimity by all the governments meeting within the European Council. Would it not be possible to interpret these agreements as decisions of the representatives of the governments of the Member States meeting within the Council? These acts or decisions have generally a character of international law, but may in certain cases form part of Community law and as such they are not subject to any rules of national constitutional law on the conclusion of international agreements.

If the answer is in the affirmative, and if therefore Article 10 EC and 11(2) EU and its principles of loyalty and solidarity do apply, the question may arise whether it would have been possible for the Irish Government to avoid all the problems of the "no" vote. Was it wise to hold a referendum for treaty approval, when the outcome was so risky? Was the Irish Government guilty of not informing the Irish people satisfactorily about the objectives of the Treaty of Lisbon and of not stimulating enough "yes" votes? If that were the case, then the Irish Government is responsible for the delay in ratification (see P J G Kapteyn and Verloren van Themaat, Introduction to the Law of the European Communities, p 341, Edited by Laurence W Gormley, Third Edition, Kluwer Law International, 1998). 
As mentioned in the Financial Times of June 14, 2001, Brian Cowen, the Irish foreign minister, indicated with regard to the rejection of the Nice Treaty in 2001 that there would be no early move to put a new referendum to the people to reverse the decision on enlargement of the European Union. An identical opinion can now be put forward as regards the rejection of the Lisbon Treaty. This time Brian Cowen was Prime Minister!

The opinion expressed here to approximate constitutional provisions is also in accordance with the principle of subsidiarity, as the differences in the constitutional requirements between the Member States for the ratification of treaties may lead to bad results for European integration if the objectives of the proposed referenda are not sufficiently achieved by some governments of the Member States. Given the importance of the outcome of the referendum, should the Irish Government, which after all signed the Treaty of Lisbon, not have indicated that it would resign in the case of a NO vote?

On the one hand, it is constitutionally advisable to hold a referendum in order to comply with the requirement of Article 6 TEU which refers to the principles of democracy on which the Union is based; on the other hand, this case shows that using referenda for amendment procedures of rather complicated treaties is not always an efficient procedure and may result in unexpected and unpleasant outcomes for further European integration.

Assuming that Article $10 \mathrm{EC}$ or its principles will more or less apply in this Irish case, a short comment on the interpretation of its provisions and reference to some ECJ Decisions may be useful.

In its present wording Article 10 EC refers only to the relationship between the Community and its Member States and is formulated, moreover, as if it were a one-waystreet, that is as a duty imposed on the Member States to take all measures to promote the Community interests (see Report of the XIX FIDE Congress, Helsinki, June 1-3, 2000, p 9, W van Gerven).

The Community interests are in this case the speedy ratification of the Lisbon Treaty by all the Member States. The notion of "Member State" is a global and wide one. It covers not only the central authorities, the "executive" (the central Government), but also the local and/or regional authorities of a Member State (see Report of the XIX FIDE Congress, Helsinki, June 1-3, 2000, p 229, Jaap W de Zwaan, Idem Tijdschrift voor Europees en Economisch recht (SEW), 48e jaargang no 4, April 2000, pp 132-54).

Where clear breaches of Community law are at hand, as in violating the prohibition against discrimination, the court is not impressed, generally speaking, by a Member State invoking constitutional provisions to justify such a breach. A number of examples illustrate this attitude (see for example the ECJ decisions in Case 77/69 Commission v
Belgium [1970] ECR 237, para 15, and several judgments of February 2, 1982 in Commission v Belgium; also Jan Wouters, "National Constitutions and the European Union”, Legal Issues of Economic Integration, Volume 27, 2000 - I , pp 56 and 57, notes 127 and 128). A Member State cannot rely upon provisions of its constitution for the purpose of justifying a failure to comply with obligations and time-limits resulting from Directives (ECJ Case 100/77 Commission v Italy [1978] ECR 887, para 21, and Lenaerts/van Nuffel Constitutional Law of the European Union, pp 574 -75, Sweet \& Maxwell, London, 1999).

According to the opinion of de Zwaan, Article 10 EC encompasses an obligation of a general and broad, but not very precise, character. Thus although its merits and importance have been increasing over the years, also in the jurisprudence of the Court of Justice, the significance of Article $10 \mathrm{EC}$ in the context of the present discussion is to be seen as the reflection of a general attitude to be expected from an average and loyal Member State rather than serving as a basis to impose specific and concrete conduct on the state concerned. It may be considered as a source of inspiration for the national judiciary, nothing less but also nothing more. In our opinion, it may be also considered as a source of inspiration for the national governments to take measures to adapt its national constitution in order to avoid a ratification crisis.

From all the above-mentioned considerations, it is suggested that the following two legal and political solutions would resolve the constitutional problems in the Irish case.

In the first place, in our opinion Article $10 \mathrm{EC}$ and Article 11(2) EU may be also considered as a source of inspiration for the Irish Government to "take all appropriate measures, whether general or particular, to ensure fulfillment of the obligations arising out of this Treaty or resulting from action taken by the institutions of the Community... " To improve the support of the Irish people for its government policies and stimulate greater participation of the Irish people at these referenda it is necessary to raise awareness of the advantages of European integration. In this situation a more successful and government-friendly outcome of referenda may be expected.

In the second place, Article 10 EC (...”They shall abstain from any measure which could jeopardize the attainment of the objectives of this Treaty") may inspire the Irish Government to propose to its electorate an amendment of its constitution for example by proposing for some cases a replacement in the constitution of referenda by a Parliamentary procedure if this would improve the EU decision-making procedure and the attainment of the objectives of the Treaty, especially for complicated treaties. As such Treaty texts are not easily understood by ordinary Irish people, it seems better to submit these texts to Members of Parliament who may consult their legal staff. 
The text of the Treaty on European Union of 1991 was already very complicated, and the text of the Treaty on European Union after the Amsterdam amendment is still more inaccessible and difficult to consult because of the insertion of many new Articles, Protocols and Declarations and the renumbering of the Consolidated Treaty text. These issues are discussed in Improving the Quality of Legislation in Europe, TMC Asser Instituut, Report of the Conference, pp XXXV and XXXVI, Editors Alfred E Kellermann et al, Kluwer Law International, The Hague, 1998.

The text of the Treaty of Lisbon is even more inaccessible, complicated and difficult to understand (see Lisbon Treaty Summaries, Europa Institute of Leiden University, March 19, 2008 and "The Treaty of Lisbon, process, architecture and substance", Paul Craig, European Law Review 2008, 33(2), pp 137 - 66). It was therefore to be expected that the ordinary people of Ireland might say "no" in a referendum on a text which they did not understand, except perhaps if they were experts in European law! Moreover they have not sufficiently been aware of all the advantages of EU Membership for Ireland.

Lastly, reference should be made to the excellent suggestions made by Bruno de Witte on the legal scenarios for dealing with a ratification crisis in The EU Constitution: the Best Way Forward?, Edited by Deirdre Curtin, Alfred E Kellermann and Steven Blockmans, TMC Asser Press, 2005.

\section{CONCLUSION}

To sum up, I refer to the following legal scenarios and options which are possible in theory, but their scenarios need to be developed:
1. Partial entry into force and the creation of an "enhanced union".

2. Informal application of the Treaty, without basing it on the formal authority that would have resulted from the entry into force of that Treaty.

3. The closer cooperation mechanism which exists since the Treaty of Amsterdam but has remained unused, could operate in order to allow "willing and able" Member States to pursue deeper integration.

4. The renegotiation scenario, which I would not support since it is in my opinion not a realistic option. The Lisbon Treaty is already a political balance between conflicting interests. If you start cherry-picking you open a Pandora's box, and it will be a never-ending process.

5. Ireland could follow the example of Denmark, where voters initially rejected the Maastricht Treaty that paved the way for the European monetary union, only to vote yes after four opt-outs were guaranteed. The right way forward is to find specific national solutions that are acceptable for Ireland and the Irish people.

I believe that the last option is in the short run the best way forward.

\section{POSTSCRIPTUM}

The Financial Times carried a report on June 16 that Ireland will be offered additional guarantees of its sovereignty possibly in areas such as taxation, military policy and family law - under an emergency plan to save the Lisbon Treaty. An unnamed senior EU official is reported as saying that the solution would involve an offer of "explanatory protocols" stating explicitly that Lisbon does not affect Ireland's power to set its own tax rates, maintain its traditional neutrality and control abortion policy. EU leaders are discussing the issue, and if Brian Cowen, the Irish prime minister, supports the idea of additional protocols for Ireland, it may be possible for a detailed proposal to be presented at a subsequent EU summit in October.

It remains to be seen whether the Irish Government, having accepted the proposed protocols, would hold a second referendum. The Financial Times report quotes Jean-Claude Juncker, Luxembourg's prime minister and the EU's longestserving national leader, who feels that if Ireland found it impossible to ratify Lisbon, some countries should go ahead with deeper political and economic integration using clauses in the Nice Treaty. 